\title{
THE PROTEIN AND LIPIN CONTENT OF BLOOD SERUM IN THE NEPHRITIDES
}

\author{
MAX KAHN, M.D., PH.D. \\ NEW YORK
}

The changes that the blood undergoes in renal disease have of recent years received much attention, especially since the methods for examination of small quantities of blood for the nonprotein nitrogen fractions have been very ingeniously improved by various American scientists. The estimation of functional capacity of the kidneys as well as the art of prognosis and diagnosis have been much aided by these investigations. It is noteworthy, however, how comparatively slight is the attention that has been paid to the protein and lipin fractions of the blood of nephritic patients.

The first reliable estimation of the serum proteins was made in 1845 by Becquerel and Rodier, who reported that the total protein content was lessened in cases of Bright's disease, cardiac disease with edema and severe puerperal affections. C. Schmidt found the protein content much increased in cholera and diminished in nephritic individuals.

In normal subjects, the ratio of serum albumin to serum globulin is approximately from 1.5 to $2.0: 1$. It has been recorded by certain investigators that in chronic renal disease this ratio is markedly disturbed. In Table 1 an attempt has been made to gather from the literature the conflicting results reported. Mya and Viglezio summarized their findings as follows: In disease the albumin globulin ratio is much altered, the globulin increasing and the albumin diminishing. These alterations vary directly with those which occur in transudations. An increase of blood pressure increases the loss of albumin more than that of globulin. The investigations of von Limbeck and Pick and of Joachim seem to indicate that there is no disturbance in the albumin globulin ratio that should be especially characteristic of nephritis. Freund found that the globulin was reduced in nephritis.

In 1903, Erben reported that in chronic parenchymatous nephritis the globulin of the blood serum was much increased. But this did not seem to impress Morawitz, who, critically reviewing the literature on the subject in 1909, stated that no pathologic significance need be attached to the albumin globulin ratio changes in cases of nephritis. In this opinion, Ewing, von Noorden and others seem to concur. 
TABle 1.-Protein Estimatrons of Blood Serum by Various Authors

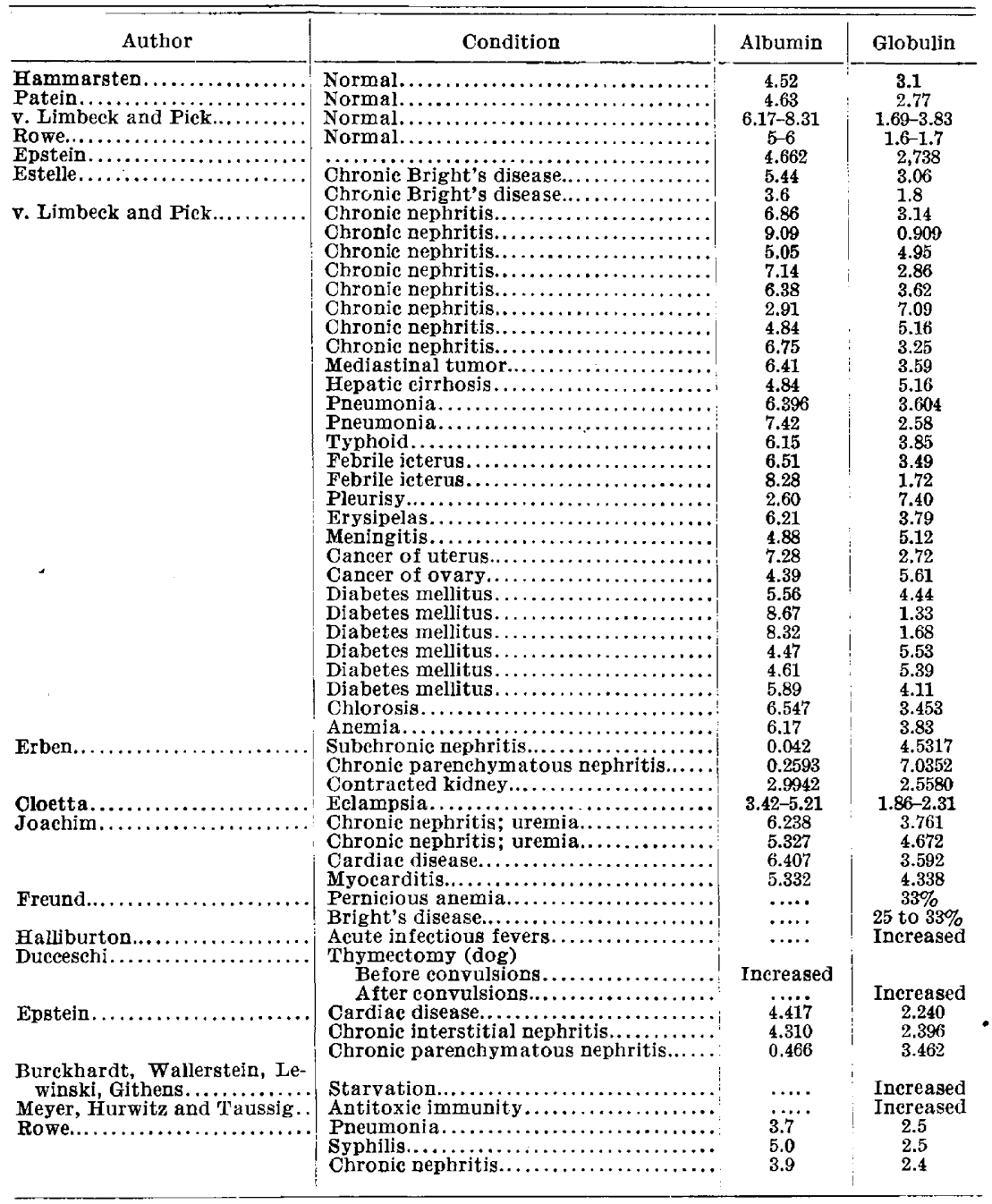

In 1912 and 1913, Epstein published three papers recording the results of chemical studies on blood serums and puncture fluids. He concluded that the globulins were increased in cardiac disease associated with decompensation and serous effusions, in pulmonary and respiratory affections (inflammatory and noninflammatory), in diabetes mellitus and in chronic parenchymatous nephritis. So far as the last named disease is concerned, he definitely corroborated Erben's results, obtaining figures for the albumin globulin ratio which indicate the marked reduction of the albumin fraction and the enormous increase in globulin. 
Based on his findings in nine cases of parenchymatous nephritis, in which, besides the globulin increase, he also found a huge amount of cholesterol in the serum, Epstein propounded his theory of the etiology of certain cases of chronic parenchymatous nephritis and of the causation of the edema in that disease. According to him, there is a group among the cases of chronic parenchymatous nephritis which is due to a constitutional disorder - of a metabolic or endocrinic nature - in which the renal or other manifestations are concomitant or secondary in point of development and importance. He does not, however, describe cases of chronic parenchymatous nephritis in which the protein or lipin fractions vary from the "metabolic" (sic) type, and which he should point out as "nonmetabolic" in nature.

He ascribes the edema to the following factor: "The loss of protein incurred by the blood serum through the continuous albuminuria causes a decrease in the osmotic pressure of the blood, which fact favors the absorption or imbibition and retention of the fluid by the tissues." The marked increase in the lipin content in these cases is taken as an evidence of the metabolic derangement of the organism, and to it is also ascribed some responsibility for the edema. On these findings, Epstein recommends for such patients a diet rich in proteins and poor in fats.

The theory of Epstein has points that are very appealing to the clinician who will venture anything to help his patient who has chronic edema. In practice, however, that group of which Epstein speaks, seems to be very rare. Of sixteen cases of chronic parenchymatous nephritis with marked edema and of seven with only slight edema, I - have not found a single case which should have the marked protein and lipin deviations indicated by Epstein, or which should be benefited (in four of the cases in which the attempt was made) by a high protein, fat poor diet.

In the examination of the patients, the blood was drawn before breakfast, and the blood serum was examined for the proteins by the method described by Morawitz. The cholesterol was determined by the method of Autenrieth and Funk as described by Hawk.

table 2.-Serum Analysis of Normal Human Beings

\begin{tabular}{c|c|c|c|c|c}
\hline Case & $\begin{array}{c}\text { Total } \\
\text { Protein }\end{array}$ & Albumin & Globulin & $\begin{array}{c}\text { Globulin, } \\
\text { per Cent. }\end{array}$ & $\begin{array}{c}\text { Cholesterol, } \\
\text { Mg. per 100 C.c. }\end{array}$ \\
\hline 1 & 8.47 & 5.43 & 3.07 & 35 & 165 \\
2 & 7.90 & 4.69 & 3.21 & 40 & 147 \\
3 & 6.76 & 4.39 & 2.37 & 35 & 139 \\
4 & 7.20 & 4.95 & 2.25 & 31 & 148 \\
\hline
\end{tabular}


KAHN-BLOOD SERUM IN NEPHRITIDES

TABLE 3.-Serum Analysis in Acute and Chronic Interstitial Nephritis

\begin{tabular}{|c|c|c|c|c|c|}
\hline Case & $\begin{array}{c}\text { Total } \\
\text { Protein }\end{array}$ & Albumin & Globulin & $\begin{array}{l}\text { Globulin, } \\
\text { per Cent. }\end{array}$ & $\begin{array}{l}\text { Cholesterol, } \\
\text { Mg. per } 100 \text { C.c. }\end{array}$ \\
\hline $\begin{array}{c}\text { Acute } \\
\text { Nephritis } \\
1 \\
2 \\
3 \\
4 \\
5 \\
6 \\
\text { Chronic } \\
\text { Interstitial } \\
\text { Nephritis } \\
7 \\
8 \\
9 \\
10 \\
11 \\
12 \\
13 \\
14\end{array}$ & $\begin{array}{l}8.67 \\
7.42 \\
7.06 \\
6.53 \\
7.07 \\
8.66 \\
7.53 \\
7.74\end{array}$ & $\begin{array}{l}4.89 \\
4.37 \\
4.44 \\
3.88 \\
4.32 \\
5.73 \\
4.86 \\
4.59\end{array}$ & $\begin{array}{l}3.78 \\
3.05 \\
2.62 \\
2.65 \\
2.75 \\
2.93 \\
2.67 \\
3.15\end{array}$ & $\begin{array}{l}43 \\
41 \\
37 \\
40 \\
38 \\
34 \\
35 \\
40\end{array}$ & $\begin{array}{l}220 \\
180 \\
175 \\
164 \\
210 \\
193 \\
139 \\
148\end{array}$ \\
\hline
\end{tabular}

TABle 4.-Serum Analyses in Cases of Chronic Parenchymatous NePHRITIS

\begin{tabular}{|c|c|c|c|c|c|}
\hline Case & $\begin{array}{c}\text { Total } \\
\text { Protein }\end{array}$ & Albumin & Globulin & $\begin{array}{l}\text { Globulin, } \\
\text { per Cent. }\end{array}$ & $\begin{array}{l}\text { Cholesterol, } \\
\text { Mg. per } 100 \text { C.c. }\end{array}$ \\
\hline $\begin{array}{r}1 \\
2 \\
3 \\
4 \\
5 \\
6 \\
7 \\
8 \\
9 \\
10 \\
11 \\
12 \\
13 \\
14 \\
15 \\
16 \\
17 \\
18 \\
19 \\
20 \\
21 \\
22 \\
23\end{array}$ & $\begin{array}{l}6.00 \\
7.42 \\
6.78 \\
4.24 \\
5.90 \\
5.81 \\
5.58 \\
7.60 \\
5.76 \\
5.73 \\
6.09 \\
6.16 \\
6.74 \\
6.75 \\
7.13 \\
6.82 \\
6.41 \\
7.33 \\
5.72 \\
7.73 \\
6.04 \\
6.03 \\
6.47\end{array}$ & $\begin{array}{r}3.72 \\
4.75 \\
4.41 \\
2.93 \\
3.72 \\
3.37 \\
3.41 \\
4.26 \\
3.75 \\
3.84 \\
4.14 \\
3.76 \\
3.98 \\
4.05 \\
4.14 \\
4.37 \\
4.17 \\
4.62 \\
3.95 \\
4.72 \\
3.87 \\
3.98 \\
4.27\end{array}$ & $\begin{array}{l}2.28 \\
2.67 \\
2.37 \\
1.31 \\
2.18 \\
2.44 \\
2.17 \\
3.34 \\
2.01 \\
1.89 \\
1.95 \\
2.40 \\
2.76 \\
2.70 \\
2.89 \\
2.45 \\
2.24 \\
2.71 \\
1.77 \\
3.01 \\
2.17 \\
2.05 \\
2.20\end{array}$ & $\begin{array}{l}38 \\
36 \\
35 \\
31 \\
37 \\
42 \\
39 \\
44 \\
35 \\
33 \\
32 \\
39 \\
41 \\
40 \\
42 \\
36 \\
35 \\
37 \\
31 \\
39 \\
36 \\
34 \\
34\end{array}$ & $\begin{array}{l}155 \\
174 \\
183 \\
194 \\
167 \\
139 \\
225 \\
184 \\
137 \\
173 \\
275 \\
216 \\
274 \\
139 \\
164 \\
144 \\
153 \\
149 \\
162 \\
166 \\
156 \\
165 \\
172\end{array}$ \\
\hline
\end{tabular}

TABLE 5.--Serum Analyses in Other Diseases

\begin{tabular}{|c|c|c|c|c|c|c|}
\hline Case & Diagnosis & $\begin{array}{c}\text { Total } \\
\text { Protein }\end{array}$ & $\begin{array}{l}\text { Albu- } \\
\text { min }\end{array}$ & $\begin{array}{l}\text { Glob- } \\
\text { ulin }\end{array}$ & $\begin{array}{c}\text { Glob- } \\
\text { ulin, } \\
\text { per } \\
\text { Cent. }\end{array}$ & $\begin{array}{l}\text { Choles- } \\
\text { terol, } \\
\text { Mg. per } \\
\text { 100 C.e. }\end{array}$ \\
\hline $\begin{array}{r}1 \\
2 \\
3 \\
4 \\
5 \\
6 \\
7 \\
8 \\
9 \\
10 \\
11 \\
12\end{array}$ & 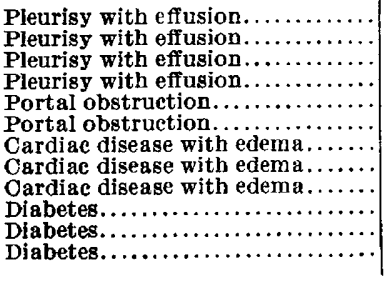 & $\begin{array}{l}6.40 \\
7.48 \\
7.85 \\
6.95 \\
7.07 \\
6.69 \\
7.17 \\
6.69 \\
6.86 \\
6.82 \\
7.62 \\
6.69\end{array}$ & $\begin{array}{l}4.16 \\
4.19 \\
4.32 \\
4.17 \\
4.10 \\
4.22 \\
4.16 \\
3.95 \\
4.12 \\
4.16 \\
4.42 \\
3.95\end{array}$ & $\begin{array}{l}2.24 \\
3.29 \\
3.53 \\
2.78 \\
2.97 \\
2.47 \\
3.01 \\
2.74 \\
2.74 \\
2.66 \\
3.20 \\
2.74\end{array}$ & $\begin{array}{l}35 \\
44 \\
45 \\
40 \\
42 \\
37 \\
42 \\
41 \\
40 \\
39 \\
42 \\
41\end{array}$ & $\begin{array}{l}175 \\
220 \\
185 \\
147 \\
239 \\
226 \\
194 \\
148 \\
220 \\
183 \\
138 \\
195\end{array}$ \\
\hline
\end{tabular}


Without going into any painstaking argumentation, it will be seen that there is no protein change in the condition of chronic parenchymatous nephritis which is characteristic of that disease and which does not occur in the other types of the nephritides and in other diseases. The cases of so-called nephrosis which Epstein describes must be very rare, and it is possible that he has culled the instances which he reports from an extremely large number of cases of chronic parenchymatous nephritis in which the albumin globulin ratio in the serum is not markedly disturbed. If so, he fails to mention how rare these nephrosis cases are, and he fails to record his results with cases of chronic parenchymatous nephritis that are not in the so-called "metabolic or endocrinic" group. ${ }^{1}$ Several years ago, ${ }^{2}$ I had the privilege of studying a patient who was suffering from nonparasitic chyluria, whose blood contained $320 \mathrm{~mm}$. of cholesterol. The urine contained very much albumin and fat. On feeding this patient on a diet poor in fat, we were able to reduce the fat in the urine very markedly, and also to diminish somewhat the protein excretion. Is it possible that this was a type of case that Epstein describes, in whom the constant excretion of huge amounts of lipins so irritated the kidney epithelium as to induce the marked albumin excretion?

On feeding patients suffering with chronic parenchymatous nephritis a diet of whites of eggs, skimmed milk, peas and lean meat for several days it was observed (Table 6) that the albumin globulin ratio was not affected, though there was some increase in the total protein of the blood serum. The edema, however, did not diminish in the slightest degree.

Table 6.-Efffect of Feeding a Protein Rich Diet in Cases of Chronic PARENChyMatous Nephritis

\begin{tabular}{|c|c|c|c|c|c|}
\hline Case & Period & $\begin{array}{c}\text { Total } \\
\text { Protein }\end{array}$ & Albumin & Globulin & $\begin{array}{l}\text { Globulin, } \\
\text { per Cent. }\end{array}$ \\
\hline $\begin{array}{r}4 \\
8 \\
9 \\
11\end{array}$ & 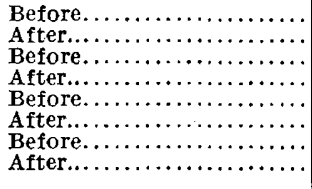 & $\begin{array}{l}4.24 \\
5.27 \\
7.60 \\
7.75 \\
5.76 \\
6.12 \\
6.09 \\
6.37\end{array}$ & $\begin{array}{l}2.93 \\
3.59 \\
4.26 \\
4.50 \\
3.75 \\
3.92 \\
4.14 \\
4.46\end{array}$ & $\begin{array}{l}1.31 \\
1.68 \\
3.34 \\
3.25 \\
2.01 \\
2.20 \\
1.95 \\
1.91\end{array}$ & $\begin{array}{l}31 \\
32 \\
44 \\
42 \\
35 \\
36 \\
32 \\
30\end{array}$ \\
\hline
\end{tabular}

It has been pointed out by Kerr, Hurwitz and Whipple that "there is a remarkable stability of the blood serum protein level in widely varying conditions of health and disease." Feeding of protein seems not to affect to any extent the serum protein content. Böhme and Reiss have shown, by the refractometer, that the concentration of

1. A personal inquiry directed to Dr. Epstein regarding these points remained unanswered.

2. Kahn and Sanes: Arch. Int. Med. 17:181 (Feb.) 1916. 
serum protein is only slightly changed after a large meal, this change following no rule, being either an increase or a decrease (Rowe). The results of Rowe show that "after four days of high protein diet there is, on the average, a slight increase in the total proteins, [with] no definite division of this increase between the albumin and the globulin fractions."

So far as the cholesterol content of the serum is concerned, one can only say that while, in general, there is an increase of this lipin in the blood serum in cases of chronic parenchymatous nephritis, this is by no means a universal rule. It must also be observed that the cholesterol content is increased in certain other conditions, as, for example, in chronic interstitial nephritis, in diseases with serous effusions (at times), and in certain metabolic derangements.

\section{CONCLUSIONS}

1. In the series of cases investigated, I did not find one case of the so-called "metabolic or endocrinic" type of chronic parenchymatous nephritis, as reported by Epstein.

2. The albumin globulin ratio does not seem to be markedly disturbed by various diseases.

3. Feeding of patients suffering with chronic parenchymatous nephritis on a protein rich, fat poor diet is a rather risky undertaking. ${ }^{3}$

140 west 69 th Street.

3. The following references may also be consulted.

Böhme: Deutsch. Arch. f. klin. Med. 103:522, 1911.

Benczur: Zeitschr. f. klin. Med. 62:164, 1909.

Boenniger: Ztschr. f. klin. Med. 42:65, 1904.

Biernacki: Ztschr. f. klin. Med. 31:279, 1897.

Becquerel and Rodier: Gaz. méd. de Par., Nos. 47-51, 1844.

Bleibtreu: Deutsch. med. Wchnschr. 19:1167, 1893.

Butjagen: Hyg. Rundschau 12:1193, 1902.

Czatary: Deutsch. Arch. f. klin. Med. 47:159, 1890; 48:358, 1891.

Cloetta: Exper. Arch. 42:453, 1899; 48:223, 1902.

Chaufford, Richet and Grigaut: Compt. rend. soc. de Biol. 67:317, 1911.

Chiray and Demanche: Compt. rend. soc. de Biol. 63:235, 1907.

Diaballa and Ketly: Deutsch. Arch. f. klin. Med., 61:76, 1898.

Erben: Ztschr. f. klin. Med. 49:450, 1903; 40:266, 282, 1900; 47:302, 1902. Ztschr. f. Heilk. 26:245, 303, 449, 1905.

Epstein: J. Exper. M. 16:719, 1912; 17:444, 1913; 20:334, 1914. Am. J. M. Sc. $154: 638,1917$.

Estelle: Rev. mens. de med. et de chir. 4:704, 1880.

Emmerich and Tsuboi: Verhandl. d. cong. f. inn. Med. 2:202, 1892.

Freund: Wien. klin. Rundschau 9:49, 1895.

Foster: Arch. Int. Med. 10:415 (Sept.) 1912.

Glaessner: Ztschr. f. exp. Path. u. Therap. 2:154, 1905.

Gottwalt: Ztschr. f. physiol. Chem. 4:423, 427, 1880.

Grenet: Compt. rend. Soc. de biol. 63:552, 1907.

Gilbert and Chiray: Comp. rend. Soc. de biol. 63:487, 1907.

Hoffmann: Arch. f. exper. Path. 89:271, 1882. 
Hoppe-Seyler: Handb. der physiol. u. path. chem. Analyse, 1893.

Hofmeister: Ztschr. f. physiol. Chem. 20:319, 1880.

Joachim: Arch. f. Physiol. 93:558, 1903.

Limbeck and Pick: Prag. med. Wchnschr. 18:21, 133, 149, 165, 1893. Deutsch. med. Wchnschr. 20:563, 1894.

Langstein and Mayer: Beitr. z. chem. Phys. u. Path. 5:69, 1904.

Leven: Jahresb. u. d. Fortschr. d. Thierchem.1:115, 1873.

McCay: Indian M. Gaz. 54:297 (Aug.) 1919. J. A. M. A. 73:1991 (Oct. 4) 1919.

Morawitz: Oppenheimer's Handb. d. Biochem. d. Menschen und d. Thiere $2: 70,1909$.

Mya-Viglezio: Arch. ital, di clin. med. 27: 1886. Reference from Limbeck's "Grundriss einer klin. Path. des Blut.," Jena, 1896, p. 100.

Rowe: Arch. Int. Med. 18:455 (Oct.) 1916.

Turner, Marshall and Lamson: J. Pharmacol. 7:129, 1915.

The American Medical Association will pay 50 cents each for the following issues of the Archives of Internal Medicine: January, March, June and August, 1918. January and July, 1916; November, 1915; January, 1911; July, 1909. Address to AMERICAN Medical Association, 535 North Dearborn Street, Chicago, Ill. 